JAMP: Jurnal Adminitrasi dan Manajemen Pendidikan

Volume 3 Nomor 3 September 2020, Hal : 283-298

Tersedia Online di http://journal2.um.ac.id/index.php/jamp/

ISSN 2615-8574 (online)

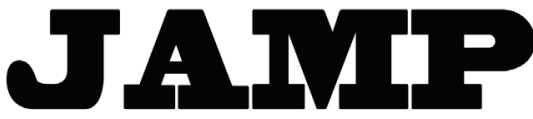

JURNAL ADMINISTRASI DAN MANAJEMEN PENDIDIKAN

\title{
MANAJEMEN KEMITRAAN MADRASAH ALIYAH DENGAN BALAI LATIHAN KERJA DALAM PROGRAM KETERAMPILAN
}

\author{
Siti Munirotul Yuanita \\ Achmad Supriyanto \\ Mustiningsih
}

\author{
Univeritas Negeri Malang, Jl. Semarang No. 5 Malang 65145 \\ Munirotulyuanita@gmail.com
}

\begin{abstract}
Abstrac: This study aims to describe the partnership management of Madrasah Aliyah (MA) with the Vocational Training Center or Balai Latihan Kerja (BLK). The method of this research used qualitative approach by using case study. Which is held at MA Ma'arif Udanawu Blitar, researcher as a key instrument. The main informan is the head of MA, the chief of MA, coordinator team, and skills teachers.The Data colection used interviews, observation, and documentation. Data analized using collection, condensation, display, and data verification. The result are: (1) the partnership based on lack of awareness and knowledge, there is no proper availability skill teachers, get a work certificate, increasing the competency of students and the skill program is absed on the need and demands of society and alumni; (2) Management of partnership is going well ; (3) there are issues on the clash of activity schedules, takes the high cost, and also the students' parents do not support the program. The solution is having a discussion with students' parents about this program; and (4) this partnership affects on the students' competency and the face of of MA and also BLK gets the participants of training.
\end{abstract}

Keywords: partnership management, skills, MA Ma’arif Udanawu

\begin{abstract}
Abstrak: Tujuan penelitian ini mendeskripsikan manajemen kemitraan MA dengan BLK. Metodenya menggunakan pendekatan kualitatif jenis studi kasus. Lokasinya di MA Ma'arif Udanawu Blitar, peneliti berperan sebagai instrumen kunci. Informan kucinya Kepala MA, Pimpinan MA, Tim Koordinator, dan Guru Keterampilan. Datanya dikumpulkan dengan wawancara observasi, dan dokumentasi. Analisisnya menggunakan display, kondensasi, penyajian, dan verifikasi data. Hasilnya: (1) kemitraan didasarkan pada kurangnya kesadaran dan pengetahuan, belum tersedia guru keterampilan, ingin memperoleh sertifikat kerja, dan meningkatkan kompetensi peserta didik, program keterampilan didasarkan tuntutan dan permintaan masyarakat dan alumni; (2) manajemen kemitraannya berjalan dengan baik; (3) terdapat masalah bentrok jadwal, mahal, dan wali murid tidak mendukung program. Solusinya dengan berkompromi dan (4) kemitraan berdampak pada kompetensi peserta didik dan citra MA serta BLK mendapat peserta pelatihan.
\end{abstract}

Kata Kunci: manajemen kemitraan, keterampilan, MA Ma'arif Udanawu

Program keterampilan merupakan wadah yang diberikan sekolah untuk menyiapkan lulusan yang mampu bersaing di dunia kerja. Program keterampilan merupakan hal yang perlu diadakan untuk meningkatkan kualitas lulusan di bidang non akademik. Kaitannya dengan proses kerja sama antara sekolah dengan pihak luar dalam program keterampilan yakni keberadaan manajemen kemitraan sekolah merupakan bagian dari serangkaian manajemen mutu pendidikan dengan mengharapkan output yang siap dan cakap dalam dunia kerja sehingga nantinya dapat segera terserap oleh dunia kerja (Suprihatiningsih, 2016). 
Penelitian Syahid (2017) menunjukkan bahwa lulusan MA sebesar 20\% yang bekerja di sektor ekonomi formal, 30\% melanjutkan ke perguruan tinggi, dan 50\% alumni masih menganggur atau setengah menganggur atau masuk ke sektor ekonomi informal. Oleh karena itu, Meneteri Agama memberikan alternatif apabila lulusan MA tidak dapat melanjutkan ke perguruan tinggi, maka MA dapat membuka program keterampilan untuk membekali peserta didik dengan keterampilan dan keahlian kerja. Hal ini sesuai dengan pendapat Dewantoro (2016) yang menyatakan tujuan program keterampilan ialah menghasilkan lulusan (output) yang ahli dan terampil dalam menguasai teknis dasar sesuai jenis program keterampilan yang diambil; memiliki semangat kemandirian dan jiwa kewirausahaan untuk berwirausaha; dan menyiapkan lulusan yang siap pakai di dunia kerja. MA yang berada di bawah naungan Kementerian Agama (Kemenag) mulai memenuhi standar yang ditetapkan di dunia kerja, dengan mengadakan program keterampilan menjadi kegiatan ekstrakurikuler ataupun materi pendidikan tambahan di sekolah (Suprihatiningsih, 2016). Ini juga dipertegas melalui adanya Surat Keputusan Direktur Jenderal Pendidikan Islam Nomor 1023 Tahun 2016 tentang Pedoman Penyelenggaraan Program Keterampilan di Madrasah Aliyah. Oleh karena itu, diharapkan banyak madrasah aliyah di Indonesia yang menghasilkan lulusan terampil yang dibutuhkan di dunia kerja.

Apabila yang dikaji program keterampilan, maka tertuju nama lembaga kursus/pelatihan/ BLK. BLK merupakan wadah atau lembaga non formal yang mengajarkan program keterampilan yang dapat dipilih sesuai dengan bakat dan minat peserta didik, diantaranya ialah modelling, salon kecantikan, tata busana/menjahit, tata boga, presenter, elektronik, otomotif, komputer, dan mengelas (Krishnawati \& Suryani, 2010). Dalam Surat Keputusan Direktur Jenderal Pendidikan Islam Nomor 1023 Tahun 2016 tentang Pedoman Penyelenggaraan Program Keterampilan di Madrasah Aliyah dikatakan bahwa Madrasah Aliyah penyelenggara program keterampilan dapat bekerja sama dengan BLK, Dunia Usaha dan Dunia Industri (DUDI), dan lembaga sertifikasi lainnya dalam mempermudah dan meningkatkan kualitas program keterampilan di MA.

Manajemen kemitraan sekolah pernah diteliti oleh Ixtiarto \& Sutrisno (2016) mengenai kemitraan SMK dengan DUDI yang menyatakan bentuk kemitraan yang sekolah dengan pihak luar, yaitu sinkronisasi kurikulum, pemagangan atau praktik kerja industri (Prakerin), pelatihan, dan penyaluran lulusan. dan penelitian dari Lestari \& Pardimin (2019) mengenai manajemen kemitraan sekolah dengan DUDI untuk meningkatkan kompetensi lulusan SMK menunjukkan bahwa terdapat permasalahan yang terjadi dalam hubungan kemitraan dan memberikan solusi pemecahan pada permasalahan tersebut. sedangkan untuk program keterampilan pernah diteliti oleh Syahid (2017) mengenai pengembangan keterampilan vokasional di MA yang menatakan terdapat 5 model pelaksanaan keterampilan, yakni ekstrakurikuler; intrakurikuler; intrakurikuler + BLK, Balai Latihan Pendidikan Teknik (BLPT), perusahaan; intrakurikuler + BLK, BLPT, perusahaan, Perguruan Tinggi (PT); dan Madrasah Aliyah Kejuruan (MAK).

MA Ma'arif Udanawu Blitar merupakan madrasah aliyah yang berada di Kabupaten Blitar Jawa Timur. MA ini memiliki nama MA Ma'arif plus Keterampilan setelah mendapat Surat Keputusan Direktur Jenderal Pendidikan Islam Nomor 4924 Tahun 2016 tentang Penetapan Madrasah Aliyah Penyelenggara Program Keterampilan sehingga MA dapat melaksanakan program keterampilan dalam kegiatan intrakurikuler dan sering dijuluki sebagai MA yang setara dengan Sekolah Menengah Kejuruan (SMK) karena mempunyai program unggulan "3 in 1 Plus" yang berarti MA Ma'arif mempunyai ilmu agama, mempunyai pengetahuan umum layaknya SMA, dan mempunyai program keterampilan yang setara dengan SMK dan mempunyai sertifikat kerja setelah mengadakan kemitraan dengan BLK. Keunikan laiannya yang dimiliki MA yakni melaksanakan program keterampilan masuk kegiatan intrakurikuler tapi tetap melaksanakan kerja sama dengan BLK dalam melaksanakan sertifikasi dan uji kompetensi nasional. Selain itu, MA Ma'arif merupakan satu-satunya dari dua MA di Blitar yang ditunjuk sebagai madrasah plus keterampilan.

Berdasarkan beberapa penelitian yang dipaparkan di atas, diketahui belum ada yang benar-benar mengungkapkan mengenai manajemen kemitraan MA dengan BLK dalam program keterampilan. Oleh karena itu peneliti pada penelitian ini akan membahas mengenai kemitraan MA dengan BLK 
dalam program keterampilan dengan tujuan mendeskripsikan latar belakang kemitraan dan pelaksanaan program keterampilan, proses manajemen, keuntungan, dan masalah serta solusi kemitraan MA Ma'arif Udanawu dengan BLK.

\section{METODE}

Penelitian ini menggunakan pendekatan kualitatif dengan jenis penelitian studi kasus untuk memahami secara utuh dan mendalam tentang manajemen kemitraan MA dengan BLK dalam program keterampilan. Penelitian ini dilakukan di MA Ma'arif Udanawu Blitar yang terletak di Jalan Raya Bakung, Kecamatan Udanawu, Kabupaten Blitar. Peneliti pada penelitian ini berperan sebagai instrumen kunci dan informan dari penelitian ini terdiri dari 14 orang yakni 8 guru keterampilan, pimpinan MA, kepala MA, kepala tata usaha, 3 tim koordinator keterampilan. Teknik pengumpulan data yang digunakan yakni teknik wawancara, observasi, dan dokumentasi. Analisis data dalam penelitian ini dilakukan selama di lapangan dan setelah selesai di lapangan. Kegiatan analisis data dilakukan melalui proses pengumpulan data, reduksi data, penyajian data, dan verifikasi data. Setelah itu pengecekan keabsahan data dilakukan dengan menggunakan triangulasi waktu, sumber, dan teknik atau metode; pengecekan anggota; meningkatkan ketekunan; dan kecukupan bahan referensi.

\section{HASIL}

\section{Latar Belakang Kemitraan dan Pelaksanaan Keterampilan MA Ma'arif Udanawu dengan BLK}

Latar belakang kemitraan MA dengan BLK terjadi karena kurangnya kesadaran dan pengetahuan guru; tidak tersedianya SDM atau tenaga pengajar keterampilan; memudahkan pelaksanaan program keterampilan dan mendapat sertifikat kerja; serta untuk meningkatkan kompetensi peserta didik agar layak kerja dan diperhitungkan di dunia kerja karena mempunyai sertifikat dari BLK yang diakui otoritasnya oleh pemerintah, masyarakat, dan dunia kerja. Prinsip kemitraan yang dijalankan MA dengan BLK, antara lain prinsip saling menguntungkan, prinsip saling percaya, dan prinsip komunikasi yang baik. Bentuk dari kemitraan MA dengan BLK, yaitu: pelatihan, uji kompetensi, sertifikasi layak kerja bagi peserta didik dan kompeten mengajar bagi guru, serta pengarahan dan konsultasi.

Pelaksanaan program keterampilan di MA Ma'arif Udanawu dilaksanakan sejak tahun 2008 dengan BLK sebagai mitranya. Program keterampilan awalnya masuk kegiatan ekstrakurikuler dan di tahun 2016 dan setelah mendapatkan Surat Keputusan Direktur Jenderal Pendidikan Islam Nomor 4924 Tahun 2016, MA melaksanakan program keterampilan sendiri atau masuk intrakurikuler dalam Kegiatan Belajar Mengajar (KBM). Latar belakang program keterampilan terjadi karena tuntutan dan permintaan masyarakat untuk menyiapkan lulusan yang siap kerja, sedangkan bagi masyarakat yang menyekolahkan anaknya, menginginkan anaknya memiliki ilmu keterampilan terutama bagi yang tidak melanjutkan ke perguruan tinggi agar punya bekal keahlian. Setelah booming-nya SMK masyarakat semakin mendesak MA harus memiliki program keterampilan, sehingga MA mengeluarkan program unggulan " 3 in 1 plus" sebagai motto MA, jadi MA tidak hanya memiliki bekal agama dan ilmu umum yang setara dengan SMA, tetapi juga memiliki bekal keterampilan dan fasilitas seperti SMK. Program keterampilan bertujuan untuk membekali anak-anak keterampilan; menjadikan anak-anak menjadi pribadi mandiri, dapat bekerja, serta mendirikan lapangan pekerjaannya sendiri; dan menjadikan anakanak siap pakai dan siap kerja setelah lulus.

\section{Proses Manajemen Kemitraan dalam Program Keterampilan (Perencanaan, Pengorganisasian, Pelaksanaan, dan Pengawasan)}

Perencanaan kemitraan yang dilakukan madrasah sudah mempunyai tujuan yang jelas yakni ingin siswanya yang lulus dari madrasah dapat menjadi wirausaha dari keterampilan yang didapat; setelah adanya tujuan tersebut madrasah melaksanakan pengumpulan data berupa pemberian kuesioner kepada peserta didik tentang minat peserta didik untuk ikut keterampilan; 
lalu dikomunikasikan kepada BLK tentang kerja samanya seperti apa, bentuk kerja samanya bagaimana, kegiatannya seperti apa, dan anggarannya berapa; setelah itu pengajuan proposal Memorandum of Understanding (MoU) kepada BLK yang berisi tentang hal yang sudah dikomunikasikan, jurusan yang akan dibuka, jumlah peserta, dan lama jam keterampilan. Semua hal tersebut, terikat jangka waktu yang sudah ditetapkan.

Upaya yang dilakukan MA dalam menyiapkan program keterampilan ialah: bekerja sama dengan BLK, DUDI, dan Dinas Sosial; menyiapkan program keterampilan menjadi kegiatan intrakurikuler; menyiapkan akreditasi madrasah; mendapat pengusulan dari Kemenag dan survey dari Kemenag; mendapat SK Dirjen; menyiapkan kurikulum karena program keterampilan masuk dalam KBM reguler dan dalam satu minggu ada 4 jam pelajaran; menyiapkan tenaga pendidik dan SDM program keterampilan yang kompeten; melengkapi infrastruktur atau Sarpras keterampilan (Sarpras yang ada di MA Ma'arif Udanawu tergolong sudah lengkap, hal ini dibuktikan dari survey Kanwil Kemenag Provinsi yang menyatakan bahwa secara Sarpras sudah memenuhi kelengkapan pelaksanaan program keterampilan); menyiapkan peserta didik program keterampilan, didapat dari pendaftaran peserta didik baru yang diwajibkan memilih jurusan sesuai minatnya; dan menyiapkan pembiayaan tempat, peralatan, SDM, dan praktik atau operasional.

Dokumen yang diajukan untuk menjadi madrasah penyelenggara program keterampilan, yaitu dokumen kurikulum; proposal; foto dan video pembelajaran keterampilan, serta Sarpras madrasah; fotokopi akreditasi madrasah; fotokopi izin operasional pendirian madrasah, surat pernyataan kesanggupan melaksanakan keterampilan di MA; daftar inventaris Sarpras keterampilan; surat rekomendasi dari Kemenag Kabupaten; daftar guru, riwayat hidup, ijazah terakhir, dan sertifikat keahlian; serta fotokopi surat pengangkatan kepala madrasah, riwayat hidup, dan ijazah terakhir kepala MA.

Alur pengajuan menjadi MA penyelenggara program keterampilan yaitu mengajukan proposal ke Kemenag Kabupaten beserta bukti-bukti pendukungnya, lalu dari Kemenag Kabupaten diajukan ke Kemenag Provinsi, setelah itu Kemenag Provinsi melakukan verifikasi dengan mendatangi madrasah langsung, Kemenag melaksanakan pembahasan mengenai layak tidaknya penyelenggaraan program keterampilan, setelah itu dari Kemenag Provinsi proposal tersebut diajukan ke pusat, dan turun menjadi SK Dirjen Pendidikan Islam beserta kurikulumnya.

Pengorganisasian yang dilaksanakan MA Ma'arif dalam kemitraan yaitu melaksanakan pembagian tanggung jawab dan kewajiban antara pihak MA dengan BLK dan untuk guruguru yang berkompeten sebagai tambahan tugas sebagai tim koordinator keterampilan, Waka kurikulum, guru keterampilan, tata usaha, Waka Sarpras, Waka kesiswaan, dan Waka Humas dengan saling berkoordinasi. Selain bermitra dengan BLK, MA juga bermitra dengan Dinas Sosial dan DUDI dalam pelaksanaan program keterampilan.Pelaksanaan dari kemitraan program keterampilan ialah madrasah menyiapkan peserta didik, tempat, dan fasilitas dalam program keterampilan sampai uji kompetensinya. BLK yang menyiapkan instruktur uji kompetensi, melaksanakan uji kompetensi kepada peserta didik, dan membuat sertifikat. Jika diteliti ulang pelaksanaan dari program keterampilan ini sama dengan kewajiban yang dilaksanakan MA dengan BLK pada MoU.

Program keterampilan MA dilaksanakan dengan menggunakan sistem moving class, sehingga pada jam yang sudah dijadwalkan, anak-anak dari kelas yang berbeda namun memilih jurusan keterampilan yang sama akan bergerak menuju laboratorium keterampilan sesuai dengan jurusannya. Model dari pelaksanaan program keterampilan di madrasah masuk ke dalam kurikulum atau masuk kegiatan intrakurikuler. Pelaksanaan program keterampilan 
melibatkan BLK dalam melaksanakan uji kompetensi peserta didik yang dilaksanakan di kelas 11, menjelang liburan semester dalam jangka waktu tertentu, dan juga ditutup dengan pelaksanaan ujian akhir semester.

Jenis program keterampilan yang dilaksanakan di MA MA'arif ada 7, yaitu Teknik dan Bisnis Sepeda Motor (TBSM), Teknik Komputer dan Jaringan (TKJ), Rekayasa Perangkat Lunak (RPL), desain grafis komputer, tata busana, tata boga, dan tata rias atau Tata Kecantikan Kulit dan Rambut (TKKR).

Struktur kurikulum program keterampilan yang dilaksanakan di madrasah yaitu tetap berpedoman pada Keputusan Direktur Jenderal Pendidikan Islam Nomor 1023 Tahun 2016 tentang Pedoman Penyelenggaraan Program Keterampilan di Madrasah Aliyah, namun tetap dikembangkan oleh madrasah yang disesuaikan dengan kebutuhan masyarakat setempat dan anak-anak atau merupakan muatan lokal yang masuk pada pembelajaran lintas minat.

Materi yang diajarkan di madrasah disesuaikan dengan pedoman yang ada di Keputusan Direktur Jenderal Pendidikan Islam Nomor 1023 Tahun 2016 tentang Pedoman Penyelenggaraan Program Keterampilan di Madrasah Aliyah namun tetap dikembangkan MA sesuai dengan lingkungan atau kebutuhan masyarakat dan peserta didik melalui MGMP program keterampilan.

Pengelolaan pembelajaran program keterampilan di MA Ma'arif Udanawu dimulai saat tahun ajaran baru, guru membuat rancangan, yang terdiri dari visi dan misi program keterampilan yang diampu, arah kerja peserta didik setelah lulus, dan merancang kegiatan peserta didik persemester dan pertahun. Selanjutnya guru mengikuti MGMP program keterampilan rutin dalam menyiapkan RPP, silabus, materi dan buku ajar, waktu pembelajaran, serta berapa persentase pemberian praktik dan teorinya diajar pada program keterampilan, dan yang terakhir ialah proses pembelajaran tatap muka yang dilakukan guru ke peserta didik dengan mengaplikasikan semua yang sudah dirancang dan dipersiapkan sebelumnya.

Lama waktu pembelajaran keterampilan di MA Ma'arif Udanawu 4 jam pelajaran, namun pada keterampilan TBSM ialah 6 jam pelajaran. Lama satu jam pelajaran adalah 45 menit. Pembelajaran keterampilan ini dilaksanakan untuk kelas X dan kelas XI. Pada tahun ajaran depan MA menetapkan lama keterampilan ialah 6 jam dan masuk kurikulum reguler yang diatur Waka kurikulum.

Sistem penilaian yang berada di MA Ma'arif mengikuti peraturan paten dari pusat yang terdiri dari afektif, kognitif, dan psikomotorik dan dilakukan setiap hari oleh guru. Untuk evaluasinya ada ulangan harian, tugas, UTS dan UAS. Terdapat tes teori dan praktik, secara kelompok dan secara individu, pembelajarannya $30 \%$ dari teori dan $70 \%$ praktik. Evaluasi dan penilaian tertuang dalam raport dan sertifikat dari BLK. Untuk uji kompetensi yang dilakukan oleh BLK dituangkan dalam bentuk sertifikat yang dilaksanakan di akhir semester khusus kelas 11 selama selama 2 minggu, 120 jam tatap muka.

Pengawasan yang dilakukan di MA Ma'arif Udanawu pada kemitraan dengan melakukan kegiatan pemantauan secara berkelanjutan dan sistematis, menemukan masalah atau penyimpangan dari SDM madrasah; evaluasi; melakukan tindak lanjut melalui perbaikan; pengawasan dilakukan secara langsung dan tidak lanngsung.

\section{Masalah dan Solusi dalam Kemitraan MA Ma'arif Udanawu dengan BLK}

Masalah yang dihadapi madrasah dalam kemitraan dengan BLK ialah bentroknya jadwal reguler madrasah dengan jadwal kegiatan BLK serta biaya atau anggaran yang tidak sedikit untuk melaksanakan uji kompetensi dan memperoleh sertifikat dari BLK, sehingga dari besarnya biaya ada beberapa wali peserta didik yang tidak mendukung program dan banyak anak yang tidak ikut uji kompetensi.

Solusi yang dilakukan untuk mengatasi masalah mengenai bentroknya jadwal antara pihak madrasah dengan BLK dapat menggunakan cara kompromi, sehingga terjadi kesepakatan di antara keduanya dalam menentukan jadwal. Untuk masalah biaya diatasi dengan tidak mewajibkan bagi anak-anak yang lanjut pendidikan dan diwajibkan bagi anak-anak yang tidak lanjut atau langsung bekerja, serta MA juga tetap meluluskan anak-anak.

\section{Keuntungan Kemitraan MA Ma'arif Udanawu dengan BLK}

Keuntungan yang diterima MA dalam kemitraan yaitu memperoleh sumbangan ide dari BLK; 
meningkatkan citra positif dan brand MA; menjadi media promosi oleh madrasah untuk menarik perhatian masyarakat agar menyekolahkan anaknya ke madrasah; meningkatkan keterampilan peserta didik sehingga mampu bersaing di dunia usaha dan dunia kerja; peserta didik mendapatkan sertifikat layak kerja dari BLK; dan guru mendapatkan pelatihan dan diklat.

BLK juga menerima keuntungan dari adanya kemitraan dengan madrasah. Keuntungan yang diperoleh BLK dari adanya kemitraan yaitu BLK dapat menjalankan tugasnya yang diberikan pemerintah dalam memberikan pelatihan kepada masyarakat (peserta didik); program BLK dapat berjalan karena memperoleh peserta didik; dan BLK memperoleh dana dari peserta didik yang mengikuti uji kompetensi.

Dari temuan yang didapat menunjukkan latar belakang kemitraan MA dengan BLK didasari oleh kurangnya kesadaran dan pengetahuan keterampilan guru, belum tersedia guru, mempermudah pelaksanaan dan mendapat sertifikat kerja, dan meningkatkan kompetensi peserta didik. Latar belakang pelaksanaan program keterampilan terjadi karena ada tuntutan dan permintaan masyarakat menyiapkan lulusan siap kerja, banyak alumni tidak lanjut ke perguruan tinggi, dan desakan menjadi MA religius, science, and skill; proses manajemen kemitraan dalam program keterampilan untuk perencanaan kemitraan MA dengan BLK dimulai dari penetapan tujuan, pengumpulan data, komunikasi kerja sama, dan pengajuan proposal MoU, mengupayakan persiapan, dokumen, dan pengajuan madrasah program keterampilan. Pengorganisasian yang dilakukan dengan membagi tanggung jawab dan kewajiban sesuai MoU dan membagikan tugas, wewenang, dan tanggung jawab kepada guru dengan membentuk struktur organisasi; serta koordinasi dari masing-masing pihak yang bersangkutan. Pelaksanaan dari kemitraan merupakan pelaksanaan dari MoU. Program keterampilan yang dilaksanakan menggunakan sistem moving class masuk kegiatan intrakurikuler, dan uji kompetensi dilakukan oleh BLK. Pengawasan yang dilakukan yaitu dengan melakukan kegiatan pemantauan, evaluasi kegiatan , dan tindak lanjut melalui perbaikan; masalah kemitraan yang terjadi antara MA dengan BLK yaitu bentroknya jadwal kegiatan, biaya uji kompetensi mahal, dan wali peserta didik tidak mendukung uji kompetensi. Solusi pemecahannya yakni dengan berkompromi dengan BLK, tidak wajib uji kompetensi BLK bagi lulusan yang lanjut ke perguruan tinggi dan diwajibkan bagi yang tidak lanjut, dan madrasah tetap meluluskan peserta didik; dan keuntungan kemitraan antara MA dengan BLK yang didapat madrasah yaitu mendapat sumbangan ide, meningkatkan citra positif dan brand madrasah, media promosi, meningkatkan keterampilan peserta didik, mendapat sertifikat, dan guru keterampilan mendapat pelatihan dan diklat. Keuntungan yang didapat BLK yaitu dapat menjalankan tugasnya sebagai lembaga pelatihan, program dapat berjalan, dan memperoleh dana. Output dari program ini membuat keterampilan peserta didik meningkat, siap kerja, dan bersertifikat. Lebih jelasnya bisa dilihat pada gambar 1 .

\section{PEMBAHASAN}

\section{Latar belakang kemitraan dan Pelaksanaan Program Keterampilan MA Ma'arif Udanawu dengan BLK}

Kemitraan dalam program keterampilan dilatarbelakangi dari kurangnya kesadaran dan pengetahuan guru mengenai keterampilan dan tidak ada guru keterampilan. Wartanto (2010) menyatakan latar belakang sekolah melaksanakan kemitraan didasari dari adanya sumber daya lembaga pendidikan yang terbatas. Hal ini menjelaskan bahwa sumber daya sekolah berupa kurangnya guru sebagai pengajar keterampilan menjadi latar belakang kemitraan sekolah.

Kemitraan antara MA dengan BLK juga dilatarbelakangi dari adanya kemudahan dalam pelaksanaan program keterampilan dan mendapat sertifikat kerja bagi peserta didik; serta untuk meningkatkan kompetensi peserta didik agar layak kerja karena sertifikat dari BLK diakui oleh pemerintah, masyarakat, dan dunia kerja. Menurut Suprihatiningsih (2016) latar belakang pelaksanaan kemitraan dengan BLK adalah agar peserta didik MA dapat memperoleh uji kompetensi dan sertifikat kerja. Prahara (2017) menyatakan latar belakang kemitraan dengan BLK karena BLK adalah lembaga yang menyiapkan tenaga kerja kompeten, berdaya saing tinggi, dan tersertifikasi. Dari paparan yang ada, diketahui agar peserta didik meningkat kompetensi keterampilannya, layak kerja dan mendapat sertifikat kerja menjadi alasan dari MA mengadakan kemitraan dengan BLK. 


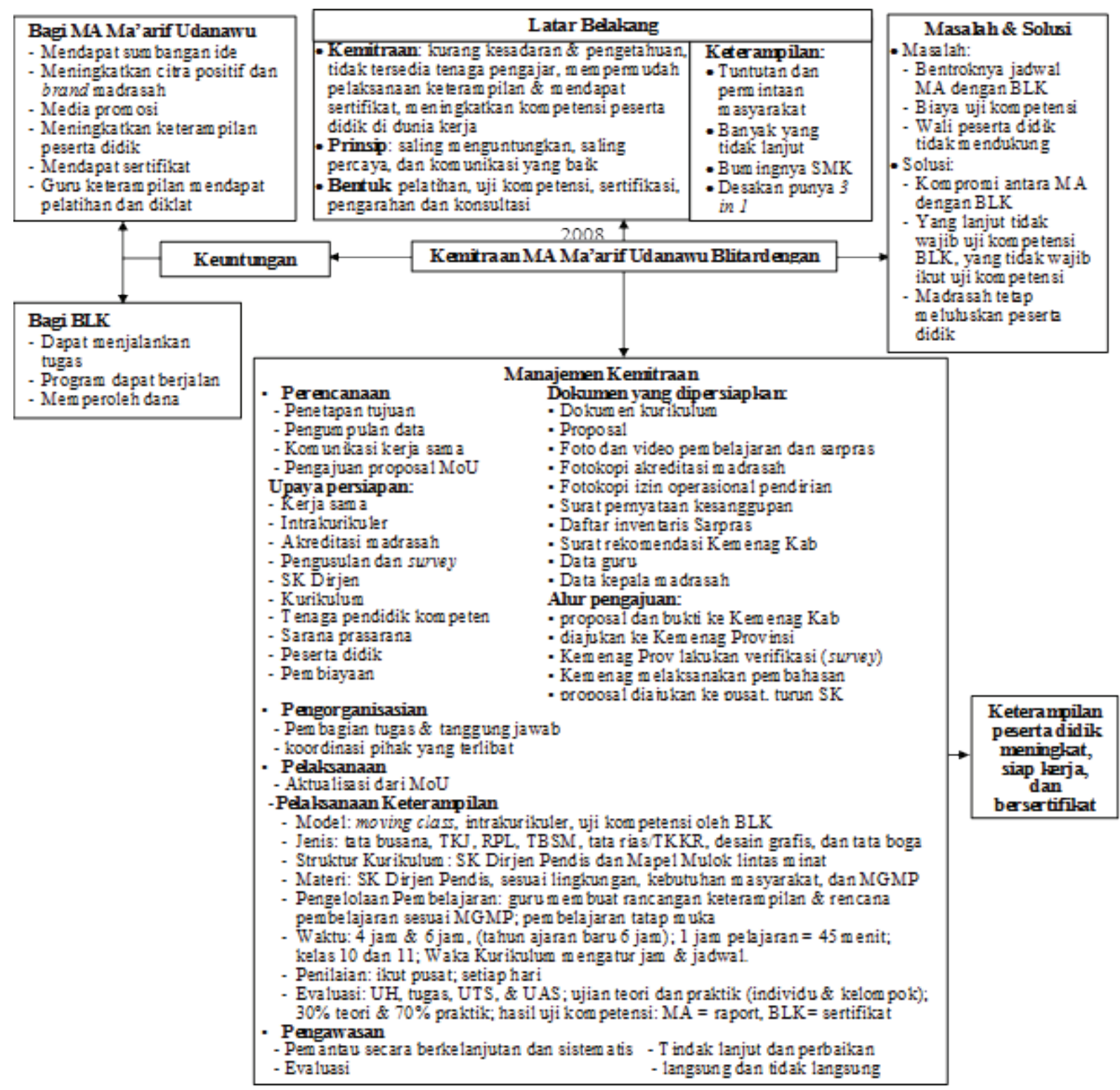

Gambar 1. Bagan Keseluruhan Temuan Penelitian

Dari temuan tersebut, ditemukan kebaharuan bahwa latar belakang kemitraan program keterampilan bukan hanya agar peserta didik meningkat kompetensi keterampilannya dan layak kerja, adanya uji kompetensi dan sertifikasi, dan kurangnya SDM atau guru di MA dalam mengajar keterampilan, tetapi juga adanya kesadaran akan kurangnya pengetahuan guru MA mengenai program keterampilan.

Prinsip kemitraan yang dijalankan MA dengan BLK, yaitu prinsip saling menguntungkan, MA merasa untung karena peserta didik mendapatkan keterampilan dan BLK diuntungkan programnya dapat berjalan karena mendapat peserta didik; prinsip saling percaya, kedua belah pihak yang saling berkomitmen dan percaya dapat menjalankan program secara konsisten; dan prinsip komunikasi yang baik, MA dan BLK saling berkomunikasi dalam menjalankan program. Wartanto (2010) menyatakan bahwa prinsip kemitraan, yaitu saling percaya, saling menguntungkan, dan komunikasi timbal balik. Hal ini membuktikan bahwa prinsip saling percaya, prinsip saling menguntungkan, dan komunikasi timbal balik menjadi prinsip yang dibangun dalam menjalin kemitraan antara MA dengan BLK.

Bentuk kemitraan MA dengan BLK, yaitu pelatihan kepada peserta didik dan diklat kepada guru untuk meningkatkan kompetensi keterampilan dan wawasan keterampilan. Ixtiarto \& Sutrisno (2016) menyatakan bentuk kemitraan MA dengan BLK yaitu pelatihan. Hal ini, dipertagas oleh pendapat Syahid (2017) yang menyatakan bahwa BLK juga memberi pelatihan bagi guru dan peserta didik. 
Bentuk kemitraan lainnya yang dilaksanakan di MA selain pelatihan yaitu, uji kompetensi yang dilakukan BLK kepada peserta didik, sertifikasi layak kerja bagi peserta didik dan sertifikat kompeten mengajar bagi guru, serta pengarahan dan konsultasi dilakukan BLK ketika MA membutuhkan saran dalam pelaksanaan atau penambahan keterampilan di MA. Pernyataan tersebut didukung oleh Peraturan Menteri Tenaga Kerja dan Transmigrasi Republik Indonesia Nomor 7 Tahun 2012 tentang Kerja Sama Penggunaan Balai Latihan Kerja oleh Swasta, ialah penyelenggaraan pelatihan kerja, uji kompetensi, pemanfaatan fasilitas BLK, dan konsultasi pelatihan. Hal ini menunjukkan bahwa bentuk kemitraan antara MA dengan BLK berupa pelatihan dan sertifikasi kepada peserta didik dan guru, uji kompetensi, serta konsultasi dan pengarahan.

Program keterampilan yang dilaksanakan di MA masuk dalam kegiatan ekstrakurikuler, namun setelah mendapatkan Surat Keputusan Direktur Jenderal Pendidikan Islam Nomor 4924 Tahun 2016 keterampilan masuk dalam kegiatan intrakurikuler. Departemen Agama Republik Indonesia (2003) memberitahukan bahwa program keterampilan yang diselenggarakan MA merupakan kegiatan ekstrakurikuler dan untuk memperoleh hasil yang maksimal, maka diintegrasikan dalam kegiatan intrakurikuler. Hal ini menunjukkan bahwa program keterampilan merupakan kegiatan intrakurikuler yang berada di MA untuk memperoleh hasil belajar peserta didik mengenai keterampilan secara maksimal.

Hal yang membuat MA melaksanakan program keterampilan ialah tuntutan dan permintaan dari masyarakat untuk menyiapkan lulusan siap pakai di dunia kerja, banyaknya lulusan yang tidak melanjutkan ke perguruan tinggi, dan desakan masyarakat setelah booming-nya SMK sebagai sekolah pesaing yang berorientasi pada penyiapan lulusan layak kerja. Suprihatiningsih (2016) menyatakan latar belakang diadakan program keterampilan ialah adanya tuntutan era persaingan bebas, banyaknya lulusan yang tidak melanjutkan ke perguruan tinggi, dan untuk menyiapkan peserta didik di dunia kerja. Dapat dikatakan bahwa adanya tuntutan dan permintaan masayarakat untuk menyiapkan lulusan siap kerja, banyak lulusan yang tidak melanjutnya ke perguruan tinggi, dan adanya sekolah pesaing menjadi alasan MA melaksanakan program keterampilan. Selain itu, MA melaksanakan program keterampilan didasari dari adanya program unggulan "3 in 1 plus" sebagai motto madrasah. Junardi (2007) mengatakan latar belakang diselenggarakannya keterampilan di MA adalah untuk membekali peserta didik keterampilan apabila tidak melanjutkan ke perguruan tinggi, adanya slogan madrasah, dan untuk mengantarkan peserta didik ke dalam dunia globalisasi yang menuntut skill dalam setiap bidangnya. Sehingga program unggulan terkait peningkatan keterampilan peserta didik yang menjadi motto MA merupakan latar belakang MA melaksanakan program keterampilan.

Dari uraian diatas dapat disimpulkan bahwa latar belakang pelaksanaan keterampilan di MA terjadi karena adanya tuntutan dan permintaan masayarakat untuk menyiapkan lulusan siap kerja, banyak lulusan yang tidak melanjutnya ke perguruan tinggi, adanya sekolah pesaing, dan adanya program unggulan terkait peningkatan keterampilan peserta didik yang menjadi motto MA.

Tujuan dari program keterampilan ialah untuk membekali anak-anak dengan keterampilan dan keahlian sesuai jurusan keterampilan yang diambil; menjadikan anak-anak menjadi pribadi mandiri, dapat bekerja, serta mendirikan lapangan pekerjaan; dan menjadikan anak-anak siap pakai dan siap kerja di masyarakat ketika lulus. Dewantoro (2016) menyatakan tujuan dari program keterampilan adalah menghasilkan lulusan yang memiliki: penguasaan keahlian atau keterampilan, semangat kemandirian dan jiwa kewirausahaan, dan siap pakai di dunia kerja. Dapat disimpulkan bahwa tujuan dari program keterampilan di MA ditujukan kepada peserta didik agar: mendapat keterampilan dan keahlian kerja; menjadi pribadi mandiri, dapat bekerja, dan berwirausaha; serta siap pakai dan siap kerja.

\section{Proses Manajemen Kemitraan dalam Program Keterampilan (Perencanaan, Pengorganisasian, Pelaksanaan, dan Pengawasan)}

Langkah-langkah perencanaan kemitraan yang dilakukan madrasah sudah mempunyai tujuan yang jelas yakni ingin lulusan dari MA dapat bekerja atau menjadi wirausaha; pengumpulan data melalui kuesioner yang diberikan kepada peserta didik untuk memilih jurusan keterampilan yang diminati; komunikasi dengan BLK terkait kerja sama yang akan dilaksanakan dalam program keterampilan 
meliputi bentuk, kegiatan, dan anggaran; pengajuan proposal MoU kepada BLK yang berisi tentang hal-hal yang sudah dikomunikasikan sampai kesepakatan dan penandatanganan. Berdasarkan pendapat Rohiat (2009) yang menyatakan langkah dalam perencanaan, yaitu menentukan tujuan yang hendak dicapai, mengumpulkan data yang diperlukan, menentukan tahapan tindakan, merumuskan pemecahan masalah dan bagaimana pekerjaan diselesaikan. Oleh karena itu dapat disimpulkan bahwa MA dalam merencanakan kemitraan sudah mempunyai tujuan yang jelas, melakukan pengumpulan data melalui kuesioner yang diberikan kepada peserta didik, menentukan tahapan tindakan melalui komunikasi dengan BLK, serta merumuskan pemecahan masalah dan tahapan tindakan dengan membuat MoU program keterampilan dan mengajukan MoU tersebut kepada pihak BLK sampai proses kesepakatan dan penandatanganan.

Dari uraian tersebut, diketahui langkah perencanaan kemitraan yaitu merumuskan tujuan yang jelas, mengumpulkan data, komunikasi dengan pihak mitra, pengajuan proposal MoU, dan kesepakatan serta penandatanganan MoU.

Upaya yang dilakukan madrasah dalam mempersiapkan program keterampilan ialah: menjalin kerja sama dengan BLK, DUDI dan Dinas Sosial, memasukkan keterampilan dalam kegiatan intrakurikuler, akreditasi madrasah A, mendapat pengusulan dari Kemenag dan adanya survey dari Kemenag, mendapat SK Dirjen Pendis, menyiapkan kurikulum: silabus, RPP atau perangkat pembelajaran keterampilan, menyiapkan SDM keterampilan yang kompeten, melengkapi Sarpras keterampilan, menyiapkan peserta didik keterampilan, dan sanggup membiayai keterampilan. Dewantoro (2016) menyatakan dalam melaksanakan keterampilan harus siap dalam: kelembagaan, kurikulum, seleksi peserta didik baru, guru, tenaga kependidikan, Sarpras, dan pembiayaan. Hal tersebut dipertegas melalui Surat Keputusan Direktur Jenderal Pendidikan Islam Nomor 1023 Tahun 2016 tentang Pedoman Penyelenggaraan Program Keterampilan di Madrasah Aliyah, upaya yang dilaksanakan MA penyelenggara program keterampilan adalah memenuhi 1) persyaratan administratif, meliputi izin operasional/pendirian MA, akreditasi minimal B, direkomendasikan Kepala Kemenag Kabupaten/Kota, diusulkan Kepala Kanwil Kemenag Provinsi dan ditetapkan oleh Direktur Jenderal Pendidikan Islam, dan pembiayaan dan 2) persyaratan teknis, meliputi mempunyai: dokumen kurikulum; guru keterampilan; Sarpras; mempunyai MoU dengan DUDI, BLK, atau Lembaga Sertifikasi Profesi lainnya. Dari pernyataan tersebut, diketahui bahwa persiapan yang dilakukan MA harus disesuaikan pada persayaratan administratif dan teknis yang ditetapkan dalam Surat Keputusan Direktur Jenderal Pendidikan Islam Nomor 1023 Tahun 2016 tentang Pedoman Penyelenggaraan Program Keterampilan di Madrasah Aliyah

Berdasarkan uraian diatas diketahui bahwa persiapan yang harus dilaksanakan MA untuk menjadi penyelenggara keterampilan yaitu bekerja sama dengan BLK dan DUDI, menjadikan keterampilan sebagai kegiatan intrakurikuler, menyiapkan kurikulum keterampilan, mendapat akreditasi minimal B, mendapat pengusulan dari Kemenag dan adanya survey dari Kemenag, mendapat SK Dirjen Pendis, menyiapkan SDM keterampilan yang kompeten, melengkapi Sarpras keterampilan, menyiapkan peserta didik keterampilan, dan menyiapkan pembiayaan keterampilan.

Dokumen yang diajukan MA Ma'arif Udanawu untuk menjadi madrasah penyelenggara program keterampilan adalah sesuai dengan persyaratan yang ada di Surat Keputusan Direktur Jenderal Pendidikan Islam Nomor 1023 Tahun 2016 tentang Pedoman Penyelenggaraan Program Keterampilan di Madrasah Aliyah. Di dalam surat keputusan tersebut MA harus memenuhi persyaratan teknis dan administratif agar menjadi MA penyelenggara keterampilan. Pada MA Ma'arif Udanawu ditemukan bahwa terdapat beberapa tambahan dokumen yang tidak disebutkan dari teori yang ada, yaitu adanya foto dan video pembelajaran serta sarpras keterampilan. Peneliti memiliki keterbatasan dalam menyajikan dokumen persyaratan administratif dan teknis dari madrasah, sehingga diharapkan peneliti selanjutnya mampu melengkapi keterbatasan penelitian ini.

Dari uraian di atas diketahui bahwa dokumen yang disiapkan untuk menjadi MA penyelenggara keterampilan keterampilan yaitu: dokumen kurikulum berupa silabus, RPP atau perangkat pembelajaran keterampilan; proposal pengajuan sebagai MA penyelenggara keterampilan; foto dan video pembelajaran keterampilan di MA; foto dan video Sarpras keterampilan; fotokopi akreditasi madrasah; fotokopi izin 
operasional pendirian madrasah, surat pernyataan kesanggupan melaksanakan keterampilan di MA; daftar inventaris Sarpras keterampilan; surat rekomendasi dari Kemenag Kabupaten; daftar guru, riwayat hidup, ijazah terakhir, dan sertifikat keahlian yang dimiliki; serta fotokopi surat pengangkatan kepala MA, riwayat hidup, dan ijazah terakhir kepala MA.

Alur pengajuan menjadi MA penyelenggara program keterampilan dengan mengajukan proposal ke Kemenag Kabupaten beserta bukti-bukti pendukungnya, lalu dari Kemenag Kabupaten diajukan ke Kemenag Provinsi, setelah itu Kemenag Provinsi melakukan verifikasi ke MA, Kemenag membahas kelayakan MA sebagai penyelanggara keterampilan, setelah itu Kemenag Provinsi proposal tersebut diajukan ke pusat, dan turun menjadi SK Dirjen Pendidikan Islam beserta kurikulumnya. Menurut Surat Keputusan Direktur Jenderal Pendidikan Islam Nomor 1023 Tahun 2016 tentang Pedoman Penyelenggaraan Program Keterampilan di Madrasah Aliyah, alur pengajuan kemitraan diawali dengan: MA menyusun proposal dan mengisi formulir dengan melampirkan dokumen persyaratan administratif dan teknis; proposal dikirim ke Kepala Kanwil Kemenag Provinsi; Kepala Seksi yang membidangi Pendidikan Madrasah dan Pengawas Madrasah melakukan verifikasi; Kepala Kantor Kemenag Kabupaten/Kota memberikan rekomendasi atas proposal Penyelenggaraan Program Keterampilan dan meneruskan berkas proposal ke Kepala Kanwil Kemenag Provinsi; tim verifikasi lapangan melakukan visitasi ke MA untuk memverifikasi dan melaporkan kepada Kepala Kanwil; Kabid Pendidikan Madrasah/Pendidikan Islam melaporkan Berita Acara Hasil Verifikasi Lapangan dan dokumen terkait kepada Kepala Kanwil Kemenag Provinsi; madrasah yang dinyatakan memenuhi persyaratan, dibuatkan Surat Usulan Madrasah Penyelenggara Program Keterampilan; Dirjen Pendis Kemenag RI menerbitkan Surat Keputusan Madrasah Penyelenggara Program Keterampilan, dan menyampaikan salinan ke Kepala MA.

Dari pernyataan tersebut diketahui bahwa dalam melaksanakan pengajuan sebagai penyelenggara keterampilan harus berpedoman pada Surat Keputusan Direktur Jenderal Pendidikan Islam Nomor 1023 Tahun 2016 tentang Pedoman Penyelenggaraan Program Keterampilan di Madrasah Aliyah yang diawali dengan mengajukan proposal dan mengisi formulir menjadi MA penyelenggara keterampilan ke Kemenag Kabupaten beserta bukti pendukungnya berupa dokumen persyaratan teknis dan administratif, serta foto dan video pembelajaran dan Sarpras keterampilan MA, lalu Kemenag Kabupaten proposal pengajuan dan bukti pendukung tersebut diajukan mengajukannya ke Kemenag Provinsi, setelah itu Kemenag Provinsi melakukan verifikasi dengan mendatangi MA langsung untuk memerikasa kesesuaian fakta, kesiapan, dan kelayakan MA dalam menyelenggarakan keterampilan, Kemenag melaksanakan pembahasan mengenai kelayakan dari MA menjadi penyelenggaraan keterampilan, setelah dinyatakan siap dan layak, dari Kemenag Provinsi proposal dan bukti pendukung diajukan ke pusat, dan turun menjadi Surat Keputusan Direktur Jenderal Pendidikan Islam mengenai penetapan MA sebagai penyelenggara keterampilan serta kurikulumnya.

Pengorganisasian yang dilaksanakan MA Ma'arif dalam kemitraan yaitu melaksanakan pembagian tugas, tanggung jawab, dan kewajiban antara pihak MA dengan pihak BLK yang tertuang dalam MoU dan juga kepada guru-guru berkompeten di MA, yang diketahui dari struktur organisasi program keterampilan dan tugas serta koordinasi dari pihak yang bersangkutan dalam program keterampilan yang terlihat dalam keseharian pelaksanaan keterampilan di madrasah. Saefrudin (2017) menyatakan pengorganisasian adalah suatu proses pembagian kerja ke dalam tugas-tugas yang lebih kecil, membebankan tugas-tugas itu kepada orang yang sesuai dengan kemampuan yang dimilikinya, dan mengalokasikan sumber daya serta mengkoordinasikan agar tujuan tercapai secara efektif. Hal ini membuktikan bahwa dalam pengorganisasian terjadi pembagian tugas dan tanggung jawab antara kedua mitra yang tertuang dalam MoU, juga terjadi pembagian tugas dan koordinasi guru yang berkompeten untuk mengelola program yang dijalankan MA dan BLK sesuai struktur organisasi program yang dibuat MA.

Dapat diketahui, dalam pengorganisasian kemitraan dengan BLK, kepala MA memberikan tugas tambahan kepada guru dalam program keterampilan yang terdiri dari tim koordinator keterampilan, Waka kurikulum, guru keterampilan, tata usaha, Waka sarana prasarana, Waka kesiswaan, dan Waka Humas. Selain bermitra dengan BLK madrasah juga melaksanakan kemitraan dengan Dinas Sosial 
dan DUDI dalam pelaksanaan program keterampilan. Hal tersebut sejalan dengan pendapat Mustika (2018) yang menyatakan pengorganisasian yang dijalin antara sekolah dengan pihak mitra menurut yaitu kepala sekolah menunjuk guru untuk diberi tambahan tugas khusus dalam kemitraan sekolah yang terdiri dari kelompok kerja praktik industri, kelompok kerja bursa khusus, dan ketua jurusan keahlian serta melakukan kerja sama dengan institusi dinas yang terkait dengan kemitraan sekolah. Hanya saja pada MA Ma'arif Udanawu belum terdapat kelompok kerja bursa khusus. Dari pernyataan tersebut, menunjukkan bahwa dalam pengorganisasian kemitraan di MA dalam program keterampilan terdapat penambahan tugas yang dilaksanakan kepala MA kepada dari tim koordinator keterampilan, Waka kurikulum, guru keterampilan, tata usaha, Waka sarana prasarana, Waka kesiswaan, dan Waka Humas.

Pelaksanaan dari kemitraan program keterampilan ialah MA menyiapkan peserta didik, tempat, dan fasilitas dalam program keterampilan sampai uji kompetensinya. BLK yang menyiapkan instruktur uji kompetensi, melaksanakan uji kompetensi kepada peserta didik, dan membuat sertifikat. Pelaksanaan kemitraan dalam program keterampilan sesuai kewajiban yang dilaksanakan MA dengan BLK pada MoU yang sudah disepakati. Pusbangtendik (2015) menyatakan pelaksanaan kemitraan adalah segala kegiatan realisasi dari sesuai MoU yang sudah ditandatangani kedua belah pihak. Hal ini menjelaskan pelaksanaan kemitraan merupakan realisasi dari MoU yang sudah disepakati pihak yang bermitra.

Program keterampilan yang dilaksanakan di madrasah menggunakan sistem moving class, sehingga pada jam yang sudah dijadwalkan, anak-anak dari kelas yang berbeda namun memilih jurusan keterampilan yang sama akan bergerak menuju laboratorium keterampilan sesuai dengan jurusan yang dipilih. Untuk model dari pelaksanaan program keterampilan di madrasah masuk ke dalam kurikulum atau masuk kegiatan intrakurikuler madrasah. Masruroh (2016) menyatakan pelaksanaan program keterampilan di madrasah dapat dilakukan dengan cara "moving class" yaitu peserta didik menuju Lab keterampilan sesuai keterampilan yang dipilih pada jam keterampilan yang sudah dijadwalkan. Dapat diketahui bahwa pelaksanaan dari keterampilan menggunakan sistem moving class.

Pelaksanaan program keterampilan masuk kegiatan intrakurikuler juga melibatkan BLK dalam melaksanakan uji kompetensi peserta didik yang dilaksanakan di kelas 11, ketika menjelang liburan semester selama jangka waktu tertentu. Temuan tersebut sama dengan model pelaksanaan keterampilan yang diungkapkan Syahid (2017) yaitu "Intrakurikuler + BLK, BLPT, Perusahaan" yakni model yang menggabungkan model intrakurikuler dengan pelatihan keterampilan yang intensif oleh BLK untuk melatih perkembangan keterampilan guru dan murid serta pelatihan ini dilakukan pada libur semester. Hal ini menunjukkan bahwa model pelaksanaan keterampilan "Intrakurikuler + BLK, BLPT, Perusahaan" merupakan model yang memasukkan keterampilan sebagai kegiatan keterampilan nemun tetap melakukan komunikasi intensif dan uji kompetensi dengan BLK.

Kemitraan dalam program keterampilan MA dilaksanakan dengan mendatangkan BLK ke MA untuk melaksanakan pelatihan, uji kompetensi, dan sertifikasi kepada peserta didik. Widodo (1998) bahwa pelaksanaan program keterampilannya ialah mendatangkan mobil training unit dari BLK ke sekolah, yaitu MA mendatangkan BLK ke MA untuk melakukan pelatihan. Berdasarkan uraian tersebut pelaksanaan keterampilan dengan mendatangkan BLK ke MA untuk melaksanakan pelatihan uji kompetensi dan sertifikasi merupakan model mendatangkan mobil training unit dari BLK ke sekolah.

Jenis program keterampilan yang dilaksanakan di MA MA'arif ada 7, yaitu TBSM, TKJ, RPL, desain grafis, tata busana, tata boga, dan tata rias atau TKKR. Menurut Surat Keputusan Direktur Jenderal Pendidikan Islam Nomor 1023 Tahun 2016 tentang Pedoman Penyelenggaraan Program Keterampilan di Madrasah Aliyah, menyatakan jenis program keterampilan pada kelompok teknologi, meliputi: teknik komputer dan jaringan, teknik otomotif, dan teknik multimedia; dan pada kelompok kejuruan, meliputi: tata busana, tata boga, dan tata rias. Selanjutnya Suprihatiningsih (2016) menyatakan jenis keterampilan, pada kelompok kejuruan, meliputi tata busana, dan tata boga.

Ada beberapa perbedaan penyebutan jurusan antara temuan deng teori yang terpapar, yakni 1) untuk TBSM pada teori disebutkan sebagai teknik otomotif, untuk jurusan RPL \& desain grafis merupakan pemecahan dari teknik multimedia. Oleh karena itu, jurusan keterampilan yang ada di MA Ma'arif diantaranya TBSM, TKJ, RPL, dan desain grafis komputer merupakan jenis keterampilan dari kelompok 
teknologi, sedangkan tata busana, tata boga, dan tata rias atau TKKR merupakan jenis keterampilan dari kelompok kejuruan.

Struktur kurikulum program keterampilan yang dilaksanakan di madrasah yaitu tetap berpedoman pada Keputusan Direktur Jenderal Pendidikan Islam Nomor 1023 Tahun 2016 tentang Pedoman Penyelenggaraan Program Keterampilan di Madrasah Aliyah, namun tetap dikembangkan oleh madrasah yang disesuaikan dengan kebutuhan masyarakat setempat dan anak-anak atau merupakan muatan lokal yang masuk pada pembelajaran lintas minat. Hal ini selaras dengan pendapat Abidah (2019) bahwa kurikulum pada program keterampilan masuk dalam mata pelajaran Muatan Lokal (Mulok) yang berada pada pelajaran lintas minat. Hal ini membuktikan bahwa struktur kurikulum keterampilan MA mengikuti Keputusan Direktur Jenderal Pendidikan Islam Nomor 1023 Tahun 2016 tentang Pedoman Penyelenggaraan Program Keterampilan di Madrasah Aliyah, yang mana mata pelajarannya merupakan muatan Mulok dan merupakan pembelajaran lintas minat.

Materi yang diajarkan di madrasah disesuaikan dengan pedoman yang ada di Keputusan Direktur Jenderal Pendidikan Islam Nomor 1023 Tahun 2016 tentang Pedoman Penyelenggaraan Program Keterampilan di Madrasah Aliyah namun tetap dikembangkan MA sesuai dengan lingkungan atau kebutuhan masyarakat dan peserta didik melalui MGMP program keterampilan. Utami (2014) menyatakan materi dalam program keterampilan disesuaikan dengan lingkungan atau daerah masingmasing melalui MGMP. Hal ini menjelaskan bahwa materi dalam program keterampilan secara umum mengikuti Keputusan Direktur Jenderal Pendidikan Islam Nomor 1023 Tahun 2016 tentang Pedoman Penyelenggaraan Program Keterampilan di Madrasah Aliyah, namun bisa dikembangkan MA yang disesuaikan dengan lingkungan, kebutuhan masyarakat, dan minat peserta didik.

Pengelolaan pembelajaran program keterampilan di MA Ma'arif Udanawu dimulai guru membuat rancangan pembelajaran keterampilan persemester dan pertahun; menyiapkan RPP, silabus, materi dan buku ajar, waktu pembelajaran, pemberian teori dan praktik (di dalam kegiatan MGMP); serta pembelajaran tatap muka. Hal ini sesuai dengan Surat Keputusan Direktur Jenderal Pendidikan Islam Nomor 1023 Tahun 2016 tentang Pedoman Penyelenggaraan Program Keterampilan di Madrasah Aliyah bahwa pengelolaan pembelajaran dengan membentuk: program pembelajaran (program tahunan dan program semester), persiapan pembelajaran berupa Rencana Pelaksanaan Pembelajaran (RPP) dan lembar praktik peserta didik (Job Sheet), dan kegiatan pembelajaran tatap muka. Hal ini menunjukkan bahwa dalam mengelola pembelajaran sebelumnya guru harus membuat rancangan program keterampilan persemester dan pertahun, mengikuti MGMP ketramplian dalam rangka menyiapkan perangkat pembelajaran meliputi, RPP, selabus, dan lain-lain, serta mengaplikasikan persiapan yang sudah dilaksanakan guru dalam pembelajaran tatap muka.

Lama pembelajaran keterampilan yang dilaksanakan di MA Ma'arif ialah 4 dan 6 jam pelajaran, satu jam pelajaran yaitu 45 menit, pembelajaran keterampilan diberikan di kelas 10 dan kelas 11, Waka kurikulum mengatur jam pembelajaran keterampilan. Dalam Surat Keputusan Direktur Jenderal Pendidikan Islam Nomor 1023 Tahun 2016 tentang Pedoman Penyelenggaraan Program Keterampilan di Madrasah Aliyah diketahui waktu pembelajaran dalam program keterampilan adalah 6 jam, per jam pelajaran adalah 45 menit, kegiatan pembelajaran dilaksanakan di kelas X, XI dan XII, dan pengaturan jadwal pelajaran keterampilan diserahkan kepada Waka kurikulum. Pada temuan dan teori terdapat perbedaan yaitu di MA Ma' arif Udanawu kegiatan pembelajaran hanya sampai kelas X dan XI, sedangkan kelas XII tidak, kemudian untuk lama pembelajaran keterampilan di MA masih ada yang 4 jam, namun untuk tahun ajaran baru akan disesuaikan semua menjadi 6 jam. Hal ini menunjukkan bahwa lama waktu pembelajaran pada MA penyelenggara keterampilan diatur dalam Surat Keputusan Direktur Jenderal Pendidikan Islam Nomor 1023 Tahun 2016 tentang Pedoman Penyelenggaraan Program Keterampilan di Madrasah Aliyah.

Sistem penilaian yang berada di MA Ma'arif mengikuti peraturan paten dari pusat yang terdiri dari afektif, kognitif, dan psikomotorik dan dilakukan setiap hari oleh guru. Untuk evaluasinya ada ulangan harian, tugas, UTS dan UAS; tes teori dan praktik, pada ujian praktik ada ujian secara bersama-sama atau kelompok dan ada ujian secara individu; 30\% teori dan 70\% praktiknya. Evaluasi dan penilaian dari uji kompetensi yang dilaksanakan oleh madrasah dituangkan ke dalam raport peserta didik. Untuk 
uji kompetensi yang dilakukan oleh BLK dituangkan dalam bentuk sertifikat yang dilaksanakan di akhir semester khusus kelas 11 selama selama 2 minggu, 120 jam tatap muka. Muttaqien (2019) yang menyatakan Penilaian dan evaluasi dilaksanakan setiap semester melalui ujian teori dan praktik untuk menguji kompetensi peserta didik meliputi sikap, kognitif, dan psikomotor sesuai materi yang sudah diajarkan guru, pada semester akhir peserta didik diberi tugas akhir sebagai syarat memperoleh sertifikat, serta uji kompetensi untuk penerbitan sertifikat, dapat bekerja sama dengan Praktisi, BLK, DU/DI, Lembaga Sertifikasi Profesi (LSP), organisasi profesi, dan lain-lain yang diakui oleh pengguna lulusan madrasah nantinya. Dalam Surat Keputusan Direktur Jenderal Pendidikan Islam Nomor 1023 Tahun 2016 tentang Pedoman Penyelenggaraan Program Keterampilan di Madrasah Aliyah dikatakan penilaian mengikuti ketentuan pemerintah atau berdasarkan Kurikulum 2013, evaluasinya dilaksanakan setiap minggu, tengah semester, dan akhir semester berbentuk teori dan praktik secara individual atau kelompok dengan bobot materi sebesar 30\% dan praktik $70 \%$, adanya pelaporan tiap semester, dan program keterampilan diakhiri dengan melaksanakan uji kompetensi pihak yang berkompeten seperti BLK dan DUDI.

Berdasarkan uraian tersebut, menunjukkan bahwa sistem penilaian mengikuti ketentuan dari Surat Keputusan Direktur Jenderal Pendidikan Islam Nomor 1023 Tahun 2016 tentang Pedoman Penyelenggaraan Program Keterampilan di Madrasah Aliyah, yang mencakup aspek kognitif, afektif, dan psikomotorik yang dilakukan setiap hari oleh guru, adanya uji kompetensi MA yang hasilnya dituangkan dalam raport dan uji kompetensi dari BLK yang hasilnya dituangkan dalam sertifikat.

Pengawasan kemitraan yang dilakukan MA dengan BLK dalam program keterampilan yaitu dengan melakukan kegiatan pemantauan secara berkelanjutan dan sistematis yang dimulai dari perencanaan program, pemaparan program, pelaksanaan, serta menemukan masalah ataupun penyimpangan dari SDM madrasah; melaksanakan evaluasi kegiatan melalui laporan pada rapat pimpinan; hingga melakukan tindak lanjut melalui perbaikan terhadap masalah dan penyimpangan yang terjadi dengan tujuan untuk memastikan bahwa pelaksanaan kegiatan mulai awal sampai akhir berjalan sesuai dengan tujuan dan program yang telah ditetapkan. Gunawan \& Benty (2017) mengungkapkan didalam pengawasan terdapat kegiatan memantau, menilai, dan laporan kemajuan disertai tindak lanjut. Hal tersebut menunjukkan bahwa di dalam pengawasan kemitraan terdapat proses pemantauan yang dilakukan mulai dari perencanaan, pelaksanaan program, menemukan masalah atau penyimpangan, kemudian melaksanakan evaluasi, melakukan perbaikan sampai tindak lanjut.

Pengawasan yang dilakukan di MA Ma' arif dilakukan secara langsung melalui pemantauan pimpinan dan tim pengawas di tempat pelaksanaan dan dilakukan secara tidak langsung melalui laporan dari pihak mitra atau BLK dan melalui laporan pada rapat pimpinan. Purwadi (2017) menyatakan pengawasan dapat dilaksanakan secara langsung dan secara tidak langsung. Hal ini menunjukkan bahwa pengawasan dalam kemitraan bisa dilakukan secara langsung melalui pemantauan dari pimpinan dan tim pengawas yang dibentuk MA, serta bisa dilaksanakan secara tidak langsung melalui laporan, berupa komunikasi antara pihak MA dengan BLK dan berupa laporan kegiatan dalam rapat pimpinan.

\section{Masalah dan Solusi dalam Kemitraan MA Ma'arif Udanawu dengan BLK}

Masalah kemitraan yang dihadapi MA dengan BLK ialah bentroknya jadwal kegiatan, ketika MA akan melaksanakan pelatihan keterampilan yang harus mendatangkan pihak BLK, namun pihak BLK tidak dapat menghadiri kegiatan tersebut karena adanya jadwal kegiatan di BLK. Selain itu, Uji kompetensi yang dilaksanakan di BLK termasuk mahal yakni Rp. 435.000, dari mahalnya biaya tersebut ada wali peserta didik yang tidak mendukung uji kompetensi yang berimbas pada banyaknya peserta didik yang tidak ikut uji kompetensi dari BLK. Lestari \& Pardimin (2019) menyatakan penghambat kemitraan sekolah adalah ketidaksesuaian waktu dalam penyelenggaraan kerja sama dan keterbatasan biaya yang diperlukan dalam rangka terjalinnya kerja sama. Dari hal tersebut terdapat kebaharuan bahwa masalah kemitraan juga terjadi karena adanya wali peserta didik yang tidak mendukung program yang dibentuk dari kerja sama antara MA dengan BLK dan adanya peserta didik yang tidak mengikuti uji kompetensi. Dari penjelasan tersebut diketahui bahwa masalah kemitraan MA dengan BLK yaitu bentroknya jadwal, biaya uji kompetensi yang mahal, dan adanya wali peserta didik yang tidak mendukung program serta banyak anak yang tidak ikut uji kompetensi. 
Solusi untuk mengatasi masalah bentroknya jadwal dapat menggunakan cara kompromi antara kedua belah pihak, sehingga terjadi kesepakatan dalam menentukan jadwal yang tepat. Untuk masalah biaya dapat diatasi dengan tidak mewajibkan bagi anak-anak yang lanjut pendidikan dan diwajibkan bagi anak-anak yang tidak lanjut atau langsung bekerja, serta madrasah juga tetap meluluskan anak-anak meskipun tidak mempunyai sertifikat dari BLK tapi tetap mempunyai keahlian di bidang jurusannya karena memperoleh pengajaran dan pelatihan keahlian dari guru keterampilan masing-masing. Lestari \& Pardimin (2019) menyatakan solusi yang dilakukan untuk mengatasi hambatan tersebut yaitu pemilihan dan penyamaan orientasi yang seiring tanpa mengesampingkan keuntungan; dan menjalin komunikasi mengenai penyesuaian waktu. Oleh karena itu, solusi kemitraannya yaitu dengan melakukan kompromi, tidak mewajibkan uji kompetensi, serta madrasah juga tetap meluluskan anak-anak.

\section{Keuntungan Kemitraan MA Ma'arif Udanawu dengan BLK}

Keuntungan yang diterima MA dalam kemitraan yaitu memperoleh sumbangan ide dalam program keterampilan dari adanya konsultasi MA dan pemberian saran dari BLK. Triwiyanto (2015) berpendapat, adanya kemitraan dalam program keterampilan sekolah mendapat keuntungan berupa memperoleh sumbangan ide dan pemikiran dari pihak mitra. Hal tersebut menunjukkan bahwa adanya kemitraan memberikan keuntungan bagi sekolah yakni mendapat sumbangan ide dari pihak mitra.

Selain mendapatkan sumbangan ide dari BLK, pada acara wisuda MA pihak BLK selalu memberikan sambutan yang berisi laporan mengenai perkembangan keterampilan peserta didik MA yang mengikuti uji kompetensi. Hal tersebut membuat banyak wali peserta didik dan masyarakat yang hadir mengetahui bahwa MA mempunyai program keterampilan yang bagus dan menghasilkan peserta didik yang unggul kompetensi keterampilannya, sehingga minat masyarakat untuk menyekolahkan anaknya semakin tinggi yang berdampak citra positif dan brand MA semakin meningkat. Adanya pelatihan, uji kompetensi, dan sertifikasi yang dilaksanakan BLK kepada peserta didik dan guru membuat peserta didik meningkat kompetensi keterampilannya, siap kerja, dan berdaya saing di dunia kerja dan usaha karena memperoleh sertifikat layak kerja, sedangkan guru memperoleh tambahan wawasan dan cara mengajar yang baik dalam keterampilan, serta memperoleh sertifikat kompeten mengajar. Peraturan Kemendiknas dalam Ixtiarto \& Sutrisno (2016) berisi bahwa keuntungan yang diterima sekolah dalam hubungan kemitraan yaitu menumbuhkan partisipasi dan minat masyarakat terhadap sekolah, untuk media promosi sekolah, dan untuk pencitraan publik.

Berdasarkan pemaparan yang ada menunjukkan bahwa keuntungan yang diterima MA dalam kemitraan yaitu memperoleh sumbangan ide, meningkatkan citra positif dan brand MA, menjadi media promosi, meningkatkan keterampilan peserta didik agar mampu bersaing di dunia usaha dan dunia kerja, peserta didik mendapatkan sertifikat layak kerja, dan guru mendapatkan pelatihan atau diklat.

Keuntungan yang diterima BLK dari kemitraan dengan MA yaitu BLK dapat menjalankan tugasnya dan program BLK dapat berjalan karena adanya peserta didik MA sebagai peserta pelatihan. Nazarudin (2018) menyatakan BLK merupakan lembaga pelatihan yang menjadi perpanjangan tangan dari pemerintah dalam mengurangi tingkat pengangguran yang ditugasi untuk memberikan pelatihan kepada masyarakat agar siap pakai di dunia kerja. Dapat diketahui bahwa keuntungan yang didapat BLK dari kemitraan dengan MA yaitu dapat menjalankan tugas dan programnya sebagai lembaga pelatihan.

BLK juga menerima sumber dana dari peserta didik yang mengikuti uji kompetensi. Aji (2019) menyatakan keuntungan yang didapat BLK dari adanya kerja sama ialah untuk menambah sumber dana dalam mengatasi masalah pembiayaan penyelenggaraan di BLK. Hal ini membuktikan bahwa BLK mendapat keuntungan berupa memperoleh sumber dana.

Berdasarkan uruaian di atas BLK mendapat keuntungan dari kemitraan dengan MA dalam program keterampilan yaitu dapat menjalankan tugasnya, program dapat berjalan, dan memperoleh dana. 


\section{KESIMPULAN}

Simpulan dari penelitian ini yakni: (1) Latar belakang kemitraan diadakan karena kurangnya kesadaran dan pengetahuan guru MA, belum tersedia tenaga pengajar, mempermudah pelaksanaan dan mendapat sertifikat kerja, serta meningkatkan kompetensi peserta didik. Latar belakang pelaksanaan program keterampilan terjadi karena ada tuntutan dan permintaan masyarakat menyiapkan lulusan siap kerja, banyak alumni tidak lanjut ke perguruan tinggi, dan desakan menjadi madrasah religius, science, and skill; (2) Perencanaan kemitraan MA dengan BLK dimulai dari penetapan tujuan, pengumpulan data, komunikasi kerja sama, dan pengajuan proposal MoU. Persiapan harus memenuhi persyaratan dari SK Dirjen Pendis. Pengorganisasian yang dilakukan MA Ma'arif Udanawu dengan BLK tugas, kewajiban, dan tanggung jawab ke BLK (dalam MoU) dan Guru MA (Struktur Organisasi). Pelaksanaan dari kemitraan merupakan pelaksanaan dari MoU antara MA dengan BLK. Program keterampilan yang dilaksanakan menggunakan sistem moving class dengan model pelaksanaan keterampilan "Intrakurikuler + BLK, BLPT, Perusahaan". Pelaksanaan keterampilan sesuai SK Dirjen Pendis kecuali ketentuan waktu dan kelas. Pengawasan kemitraan dalam program keterampilan yaitu memantau, mengevaluasi, dan memperbaiki jika ada masalah dari awal sampai akhir program berjalan. Pengawasan dilakukan secara langsung dan tidak langsung; (3) masalah kemitraannya yaitu bentroknya jadwal kegiatan, biaya uji kompetensi yang mahal, dan wali peserta didik tidak mendukung uji kompetensi dengan BLK. Solusi pemecahannya yakni dengan berkompromi dengan BLK, tidak mewajibkan uji kompetensi BLK bagi anak-anak yang lanjut pendidikan dan diwajibkan bagi anak-anak yang tidak lanjut atau langsung bekerja, serta madrasah tetap meluluskan peserta didik; (4) Keuntungan kemitraan antara MA dengan BLK yang didapat madrasah yaitu mendapat sumbangan ide, meningkatkan citra positif dan brand madrasah, media promosi, meningkatkan keterampilan peserta didik, mendapat sertifikat, dan guru keterampilan mendapat pelatihan dan diklat. Keuntungan yang didapat BLK yaitu dapat menjalankan tugasnya, program dapat berjalan, dan memperoleh dana.

\section{DAFTAR RUJUKAN}

Abidah, S. (2019). "Manajemen Pengembangan Pendidikan Keterampilan Vokasional Di MAN 15 Jakarta." UIN Syarif Hidayatullah. http://repository.uinjkt.ac.id/dspace/bitstream/123456789/46050/1/SITI\%20ABIDAHFITK.pdf (February 20, 2019).

Aji, A. (2019). "Selain Pembiayaan Ini Manfaat Lain Kerja Sama BLKPMI-BJB, (Online), , Diakses.” https:// infomitramedia.com/2019/07/24/selain-pembiayaan-ini-manfaat-lain-kerjasama-blkpmi-bjb/ (March 27, 2020).

Departemen Agama Republik Indonesia. (2003). "Pedoman Umum Program Keterampilan." https://kepri. Kemenag.go.id (February 20, 2019).

Dewantoro, H. (2016). "Inovasi Madrasah Aliyah Program Keterampilan." Silabus.mpi: Media Pendidikan. https://silabus.org/pedoman-penyelenggaraan-program-keterampilan-madrasah-aliyah/.

Direktur Jendral Pendidikan Islam. (2016). “Surat Keputusan Dari Direktur Jendral Pendidikan Islam Nomor 1023 Tentang Pedoman Penyelenggaraan Program Keterampilan Di Madrasah Aliyah Tahun 2016.” http://simpuh. kemenag.go.id/regulasi/dj_1023_16.pdf.

Direktur Jendral Pendidikan Islam. (2016). "Surat Keputusan Direktur Jendral Pendidikan Islam Nomor 4924 Tentang Penetapan Madrasah Aliyah Penyelenggara Program Keterampilan Tahun 2016.”

Gunawan, I, \& Benty, D.D.N. (2017). Manajemen Pendidikan: Suatu Pengantar Praktik. Bandung: Alfabeta.

Ixtiarto, B, \& Sutrisno, B. (2016). "Kemitraan Sekolah Menengah Kejuruan Dengan Dunia Usaha Dan Industri (Kajian Aspek Manajemen Pada SMK Muhammadiyah 2 Wuryantoro Kabupaten Wonogiri).” journals.ums 26(1). http://journals.ums.ac.id/index.php/jpis/article/view/2130 (December 18, 2019).

Junardi. (2007). "Program Pendidikan Keterampilan Di Madrasah Aliyah Ummatan Wasathan Imogiri." UIN Sunan Kalijaga. http://digilib.uin-suka.ac.id/6856/1/BAB\%20I\%20DAN\%20V.pdf (February 20, 2019).

Krishnawati, N. and Suryani, Y. (2010). Bahan Dasar Untuk Pelayanan Konseling Pada Satuan Pendidikan Menengah. III. Jakarta: Grasindo. 
Lestari, B. \& Pardimin. (2019). "Manajemen Kemitraan Sekolah Dengan Dunia Usaha dan Industri untuk Meningkatkan Kompetensi Lulusan SMK.” Media Manajemen Pendidikan 2(1).

Masruroh, Z. (2016). "Manajemen Pendidikan Keterampilan (Vocational Skill) Di MAN Kembangsawit.” Jurnal Muslim Heritage 1(2).

Menteri Tenaga Kerja dan Transmigrasi Republik Indonesia. (2012). Peraturan Menteri Tenaga Kerja Dan Transmigrasi Republik Indonesia Nomor 7 Tahun 2012 Tentang Kerja Sama Penggunaan Balai Latihan Kerja Oleh Swasta. Jakarta. https://ngada.org/bn340-2012.htm (February 20, 2019).

Mustika, R. (2018). "Manajemen Kemitraan Sekolah Dalam Meningkatkan Mutu Pendidikan (Studi Multisitus SMK Islam 1 Blitar Dan SMK Negeri 3 Boyolangu Tulungagung).” IAIN Tulungagung. http://repo.iaintulungagung.ac.id/6125/ (February 20, 2019).

Muttaqien, I. (2019). "Pengembangan Entrepreneurship Pada Program MA Keterampilan Melalui Inovasi Model Pembelajaran Teaching Factory Di MAN 2 Kulon Progo.” Jurnal Pendidikan Madrasah 4(2).

Nazarudin, R. (2018). “Analisis Peran Pelatihan Kerja oleh Balai Latihan Kerja dalam Meningkatkan Potensi Angkatan Kerja di Bandar Lampung Ditinjau dari Perspektif Ekonomi Islam (Studi pada UPTD BLK Bandar Lampung).” Universitas Islam Negeri Raden Intan. http://repository.radenintan.ac.id/3276/1/skripsi.pdf\&ve d=2ahUKEwjTsN2Eh8bqAhUIfSsKHapcCHUQFjAGegQIChAB\&usg=AOvVaw1z5hWYMFNtz1gj5Yd Cw-YO (July 12, 2020).

Prahara, H. (2017). “Balai Latihan Kerja, Sarana Mencetak Tenaga Terampil Berkualitas!” Kompas.com. https:// ekonomi.kompas.com/read/2017/09/30/080200126/balai-latihan-kerja-sarana-mencetak-tenaga-terampilberkualitas- (March 20, 2019).

Purwadi. (2017). "Pengaruh Pengawasan Langsung Dan Tidak Langsung Terhadap Efektivitas Kerja Pegawai Pada Dinas Pekerjaan Umum Dan Pemukiman Prasarana Wilayah Kota Samarinda.” Akuntabel 14(2). http:// journal.feb.unmul.ac.id/index.php/AKUNTABEL/article/download/1911/143 (February 2, 2020).

Pusbangtendik. (2015). Peningkatan Kompetensi Kepala Sekolah Dalam Mengelola Implementasi Kurikulum: Kemitraan Sekolah Dengan Pihak Eksternal , Diakses 18 Maret 2020. Jakarta: Pusbangtendik. https:// docplayer.info/290549-Kemitraan-sekolah-dengan-pihak-eksternal.html.

Rohiat. (2009). Manajemen Sekolah Teori Dasar Dan Praktek. Bandung: PT Refika Aditama.

Rusdiana. (2014). Kewirausahaan Teori Dan Praktek. Bandung: PT Pustaka Ceria.

Saefrudin. (2017). "Pengorganisasian Dalam Manajemen." Jurnal Al-Hikmah 5(2).

Suprihatiningsih. (2016). Perspektif Manajemen Pembelajaran Program Keterampilan. I. Yogyakarta: Deepublish.

Syahid, A. (2017). Pengembangan Keterampilan Vokasional Di Madrasah Aliyah. Jakarta: Education Sector Analytical and Capacity Development Partnership (ACDP). http://repository.uinjkt.ac.id/dspace/ handle/123456789/41219 (February 20, 2019).

Triwiyanto, T. (2015). “Prinsip-Prinsip Manajamen Berbasis Sekolah.” mbscenter. http://mbscenter.or.id/site/ page/372?page_action=viewdetail\&title=Prinsip-prinsip+Manajamen+Berbasis + Sekolah\&page=2/title/ Prinsip-prinsip\%20Manajamen\%20Berbasis\%20Sekolah (February 20, 2019).

Wartanto. (2010). "Membangun Jejaring Kerja." https://www.slideshare.net/SaidNafik/2704101411modul5diklatmanajemenkursus (March 2, 2019).

Widodo, N. 1998. "Pelaksanaan Program Keterampilan di Madrasah Aliyah Negeri di Jawa Tengah.” Jurnal Kependidikan 28(1). 